A NTOON GEELS

\title{
A Note on the Psychology of Dhikr
}

\section{The Halveti-Jerrahi Order of Dervishes in Istanbul}

\section{Introduction}

Prayer has often been regarded as the most central aspect of religious life, "the very soul and essence of religion" (James 1902: 365). Within worldreligions the role of prayer is particularly important in Islam. Ritual prayer (salat), performed five times a day, belongs to the fundamental obligations of all Muslims. In addition to this fact, there is another type of prayer, associated with mystical orders in all Islamic countries. It is a type of repetitive prayer, similar to for example the Jesus-prayer within Orthodox Christianity, Nembutsu within Japanese Buddhism, or Japa in Hinduism (see Anawati and Gardet 1961: 189 ff.; Gilsenan 1973: 157 ff.). Repetitive prayer ( $d h i k r$ ) in mystical Islam (Sufism) belongs to the most central activities of the orders. Despite the geographic spread of the Sufi orders (turuq) "it is rare to find in the literature any but brief accounts of its most important ritual, the dhikr" (Kennedy 1974: 205). Psychological commentaries are even more scarce. The aim of this paper is twofold: to describe this ritual as it exists today within the Halveti-Jerrahi order of dervishes in Istanbul, Turkey, and to present a preliminary psychological analysis of the ritual.

The Jerrahi branch of the Halveti (Arabic Khalwatiyya) order was founded by Pir Sultan Seyyid Muhammed Nureddin el-Jerrahi, who was born in Istanbul in the year 1089 of the Islamic era (1687). ${ }^{1}$ A few years before Kemal Atatürk closed the meeting places (tekkes) of all mystical orders (in 1925), there existed about ten tekkes belonging to the Jerrahi order. The closing of the tekkes did not prevent the members of the orders from quietly continuing with "underground" activity. Today you can still visit a number of sufi-fraternities, using a variety of names in order to "cover"

\footnotetext{
I See Yola (1982) for more information about the founder and the history of the order. See also the introduction to the Irshad of Muzaffer Ozak (Nasr 1988).
} 
their real activities. Officially, the Jerrahi branch is a "Foundation for Research and Conservation of Turkish Sufi Music and Folklore" ("Türk Tasavvuf Musikisi ve Folklorunu Arastirma ve Yasatma Vakfi"). The authorities naturally are aware of their existence, and once in a while they pay a visit in order to check if the activities are in harmony with the name on the door-plate. In one of the numerous books written by the 19 th Sheikh Muzaffer Ozak, some of them translated into English, it is clearly stated that the order is "avoiding any political involvement" (Ozak 1988: xix). The present Sheikh Sefer Efendi succeeded Sheikh Muzaffer when he passed away in $1985 .^{2}$

In the description of the background and actual practice of the $d h i k r$ ritual I have used a tripartite distinction, proposed by Sam D. Gill (1987). Gill considers prayer as "text, that is, as a collection of words that cohere as a human communication directed toward a spiritual entity ...; as act, that is, as the human act of communicating with deities including not only or exclusively language but especially the elements of performance that constitute the act ...; as subject, that is, as a dimension or aspect of religion, the articulation of whose nature constitutes a statement of belief, doctrine, instruction, philosophy, or theology" (Gill 1987: 489).

It is my conviction that religious phenomena like repetitive prayer should be considered from different levels of understanding and analysis. For several years now I have been attempting to apply a multi-dimensional model of analysis in order to study different types of intense religious experiences (see Geels 1990; Geels 1991). The basic approach in this model can be described in the following way. The starting point is the interactionistic view, according to which man must be studied in relation to his social environment. The model I usually apply is in no way controversial in its general outline. It is relatively common, for example, within psychosomatic medicine. The first and broadest level in the model is concerned with society at large, with all its norms and values, in short - society's definition of reality. The scientific discipline on which I am building here is the sociology of knowledge, more precisely the kind represented by Peter Berger and Thomas Luckmann (1966). Here we are concerned with religion as a legitimation of society at large and the life of the individual on a micro-level. As far as the present subject is concerned, this level touches upon the reality as defined by Islam, more particularly Sufism and the theory and practice of $d h i k r$ as described in the tradition.

\footnotetext{
${ }^{2}$ For a list of the furst 19 Sheikhs of the Halveti-Jerrahi order, see Sukri Efendi 1980: $69 \mathrm{f}$.
} 
The next level in this model deals with social milieu. The scientific discipline is social psychology. Relevant objects for study are, for example, the importance of the Sufi fraternity as a group and the role of the Sheikh. Especially interesting is the type of reference group theory presented by T. Shibutani (1955). A reference group is defined as "that group whose perspective is assumed by the actor as the frame of reference for the organization of his perceptual field" (Shibutani 1955: 569). The definition of the concept "perspective" is important for our purpose. A perspective is "an ordered view of one's world - what is taken for granted about the attributes of various objects, events and human nature. It is an order of things remembered and expected as well as things actually perceived, an organized conception of what is plausible and possible; it constitues the matrix through which one perceives his environment" (Shibutani 1955: 564). When studying, for example, the religious experiences of a person within a certain group it is necessary to study "how a person defines the situation, which perspective he uses in arriving at such a definition, and who constitutes the audience whose responses provide the necessary confirmation and support for this position. This calls for focusing upon the expectations the actor imputes to others, the communication channels in which he participates, and his relations with those with whom he identifies himself' (Shibutani 1955: 569).

The third level in the model focuses on man as an individual, the study of intrapsychic processes. The scientific discipline used here is psychology, particularly ego psychology and its cognitive components. At this level I will apply a model of personality, based on ego psychology (see below).

The fourth and final level is the somatic one. The scientific discipline here is physiology. What religious techniques are used to produce physiological changes? How are these changes interpreted by the individual within the frame of his conception of reality? We can see that, in the context of the somatic level, we also touch on the other levels of the model. We move from overall descriptions of reality via groups to the individual with his psychological and physiological capacities. The aim of this multi-dimensional model is a holistic description and analysis of human behaviour and experience, both in the secular and religious spheres. 


\section{Dhikr as Subject - Remembrance of God}

\section{A General Description}

Remembrance of God, dhikr, is generally divided into two branches: recollection with the tongue (dhikr jali), and recollection in the heart ( $d h i k r$ $k a f i$ ). Despite the fact that the spoken $d h i k r$ jali, most often performed collectively, plays a significant role, dhikr kafi is regarded as the superior way (Schimmel 1975: 171). Classical Sufi texts generally refer to the recollection in the heart, performed in solitude (Gardet 1965: 224).

The problem of whether $d h i k r$ should be private and silent or collective and spoken has been a matter of debate within different orders. Representatives of the two positions naturally try to find support in the Koran and the Hadiths. However, the Koran and the holy tradition are not explicit on this matter.

There are numerous verses in the Koran referring to the necessity of remembrance of God. The Koranic basis for this practice, often referred to by famous Sufi authors, is the exhortation "... mention thy Lord, when thou for gettest" (Surah 18: 24). Other frequently quoted verses are 33: 40: "O believers, remember God oft", or 13:28: "in God's remembrance are at rest the hearts of those who believe". Another verse contains a promise that the rememberer also will be remembered: "Remember me, then, and I will remember you" (Surah 2: 152). In addition to these verses there are quite a number of Hadiths supporting the practice of $d h_{i k r}{ }^{3}$

The verses quoted from the Koran do not mention how Allah is to be remembered. However, for the Sufis these verses were loaded with a specific significance: the possibility of being close to God, of a direct experience of His presence. To be near God simultaeously means to be at a distance to your self ( $n a f s$ ), the components of the human personality (see Shafii 1985). "True $d h i k r$ is that you forget your $d h i k r$ ", says an early Sufi master (quoted in Schimmel 1975: 172). Another example of this inhibition of self-consciousness, the psychological dialectic between the remembrance of God and forgetfulnuss of the self (nisyan), are the following lines, written by As-Sahlagi (quoted in Ogén 1982: 236):

Those who remember [their act of calling God to remembrance] during their calling God to remembrance are more negligent than those who are forgetful [of

${ }^{3}$ It is now regarded as highly probable that the technique of repetitive prayer was influenced by early Syrian Christianity and, earlier in history, by the Stoic philosophers ("remembrance of God" mneme Theou) and the Hebrew Bible ("remembering", zakar) See Baldick 1989: 17. 
their act of calling God to remembrance] during their calling God to remembrance for [the act of] calling Him to remembrance is other than $\mathrm{He}$.

It goes without saying that experiences of the type described, the total annihilation of self-consciousness, are not common. This brings us to the subject of different types of $d h i k r$, and whether there are stages leading to this annihilation.

Roughly speaking, there are three stages to be distinguished. The first is "dhikr of the tongue", which should be performed with the "intention of the heart", not as a routine repetition of a divine name. This stage can be further divided into two steps: a voluntary recitation, with effort; and an effortless repetition, when the dervish according to al-Ghazzali "leaves off the movement of the tongue and sees the word (or formula) as it were flowing over it" (quoted in Gardet 1965). The second stage is dhikr of the heart, also characterized by two steps, similar to the ones already mentioned. The heart ( $q a l b$ ) was regarded as the seat of the "knowledge of divine things". The third stage, finally, is the $d h i k r$ of the "inmost being" (sirr), "a substance more subtle than the spirit ( $r u h)$ ", the place of the experience of tauhid, unification. At this last stage we again touch upon the total annihilation of the self-experience, the personality of the Sufi.

In later Sufi texts this spiritual development can be described in seven stages. One example is Ash-Sha'rani, a sixteenth century Sufi writer, who explains this sevenfold dhikr in the following way (quoted in Schimmel 1975: 174):

dhikr al-lisan, with the tongue; dhikr an-nafs, which is not audible but consists of inner movement and feeling; dhikr al-qalb, with the heart, when the heart contemplates God's beauty and majesty in its inner recesses; dhikr ar-ruh, when the meditating mystic perceives the lights of the attributes; dhikr as-sirr, in the innermost heart, when divine mysteries are revealed; dhikr al-khafiy, the secret recollection, which means the vision of the light of the beauty of essential unity; and, finally, the dhikr akhfa al-khaf, the most secret of secret, which is the vision of the Reality of Absolute Truth (haqq al-yaqin).

So far we have only discussed a few basic aspects of $d h i k r$ within Sufism in general. We will now focus our interest on the Halveti-Jerrahi order of dervishes in contemporary Turkey.

\section{Dhikr as Described within the Halveti-Jerrahi Order}

The following description is based mainly on the English books written by Muzaffer Ozak, the nineteenth Sheikh of the Halveti-Jerrahi order. In 
addition to these sources I will use taped recordings of talks by Muzaffer Ozak, given in the USA at the end of the 1970s and the first half of the 80 s.

Remembrance of God has at least two different meanings. In a more general way it means for the dervish to be attentive to God, independent of what he is doing. "Whatever job he does, whatever his business may be, it never distracts him from Remembrance of God" (Ozak 1981: 60). To forget God puts man on a lower level than animals, for even the animals remember their creator. In fact, the whole of creation is in constant motion and in this motion, on different degrees of awareness, "all created things remember and glorify God, Exalted is He, in accordance with their proper motions" (Ozak 1981: $116 \mathrm{f}$.). This idea is beautifully expressed in a poem by Yunus Emre (d. ca. 1321), of which a few verses are cited below (Ozak 1981: 73):

With the rocks and mountains high, Let me call, my Lord, on Thee. At the dawn with birds that fly, Let me call, my Lord, on Thee.

With the fish beneath the sea, At the dawn, with "Woe is me!" Crazy with the cry "O He!"

Let me call, my Lord, on Thee.

During his informal discourses, Sheikh Muzaffer often refers to the verse quoted earlier from the Koran: "Remember Me, then, and I will remember you" (Surah 2: 152). In this general sense, all Sufi literature means remembrance of God. That is why the well-known Muslim scholar S. H. Nasr, in his introduction to the Irshad of Muzaffer Ozak, can write that the goal of this great book, covering almost seven hundred pages, "is to guide man to the remembrance of God, to dhikr Allah" (Nasr 1988: ix).

In a more limited sense $d h i k r$ is connected with repetitive prayer as an act, as text, i.e. the different words used, and as subject, i.e. different statements of belief, instructions, legitimations and the like, associated with $d h i k r$. The first two of these aspects will be presented below. The third dimension, or at least some parts of it, will be discussed here.

Apart from the second Surah, quoted above, Muzaffer Ozak finds Koranic justification for dhikr in several other chapters of the Holy Book, especially Surah 3: 191 (Ozak 1988: 378; Ozak 1981: 77, 98). ${ }^{4}$

4 Other verses quoted by Sheikh Muzaffer are 33: 41; 29: 45; 62: 10 (Ozak 1988: $378)$. 
those that remember God when standing, sitting, and lying down, and reflect on the creation of the heavens and the earth, saying: 'Lord, You have not created this in vain. Glory be to You!'

In a commentary on this verse Sheikh Muzaffer underlines the importance of remembrance in all three basic pastures. The reason is permanent remembrance and therefore the avoidance of sinful acts and disbelief; the reward is to be remembered at the day of resurrection (Ozak 1988: $385 \mathrm{f}$.).

Muzaffer Ozak presents many arguments in favour of public dhikr, as against private, silent $d h i k r$. Like other Sufis, he regards the ritual prayer (salat, Turkish namaz), shared with all Muslims, as the greatest $d h i k r$ of all (cf. Schimmel 1990: 187). Three out of five daily prayers, Sheikh Muzaffer continues, are pronounced aloud. In addition to that there is the Friday prayer, the recitations of Allahu Akbar, "God is greater [than everything]", and so on. "What greater proof and evidence could there be, therefore, for the permissibility of public dhikr?" (Ozak 1981: $70 \mathrm{f}$.).

Muzaffer Ozak also argues in favour of the dervishes' different movements, like whirling, circling, and turning. These practices are justified in the Koran, where it is written that "you shall see the angels circling around the Throne, giving glory to their Lord" (Surah 39: 75, quoted by M. Ozak in Ozak 1981: 129). The Prophet was the first to practise whirling, which was also legitimated by A bu Bakr, Ali, and the founders of the four schools of Islamic law (Ozak 1981: $122 \mathrm{f}$.). The circumambulation and turning around the Kaba in Mecca is also a kind of whirling (Ozak 1981: 77). Again we can notice how Muzaffer Ozak, like other Sufi writers, refers to basic Muslim activities like the ritual prayer and the circumambulation around the Kaba as a legitimation of traditional Sufi ceremonies.

It is striking that Muzaffer Ozak primarily refers to the Prophet Muhammed and his successors. References to famous Sufi authors are scarce. Sufi practices of the Jerrahi order are, at least in the literary expression of Sheikh Muzaffer, connected with basic aspects of Islam in general. This observation does not mean, of course, that connections with the mystical tradition are missing. As in most other types of religious mysticism one should always be reminded of the distinction between "outer" (zahir) and "inner" (batin) meanings, as far as Koranic interpretation and religious practices are concerned. In connection with a discourse on ritual prayer (salat), Muzaffer Ozak writes that every element of it has "a profound inner meaning in addition to its formal, outer aspect." The inner meaning of washing your face, arms, head, ears or feet, as a preparation for the ritual prayer, is "among other things, promising to turn the face only 
toward Allah, to use the arms only for purposes pleasing to Him, to crown the head with His commands, not to listen to bad things, and to walk away from evil" (Ozak 1988: 168 f.).

The "inner" meanings can be concealed in different ways. One way is the excessive use of a metaphorical language, containing bacchic and erotic symbolism. Metaphors are poly-interpretative and facilitate doctrinal defence when attacked by, for example, representatives of the orthodoxy. A considerable number of Sufi saints suffered from persecution by government authorities. Some of them, like al-Hallaj and Shihabuddin Suhrawardi, were executed for their convictions. That is one of the reasons why Sufis "very early felt the necessity of developing a symbolic language which says everything to the initiated but nothing to the common man" (Schimmel 1987: 87). In the case of the Jerrahis, there exist numerous short stories containing both an outer and an inner, spiritual meaning (see e.g. Ozak 1988: $168 \mathrm{f}$.). One of my informants from the Jerrahi order mentions another factor, far more important to the dervishes themselves: the impossibility to put inner experiences into words.

Another way of guarding the esoteric dimensions of the tradition is to keep parts of it secret (see Schimmel 1987). In one of the unpublished pamphlets of the Jerrahis, the "Question Manual" (Sualname), questions are often answered with phrasings like "that is one of the secrets" or "more cannot be told to non-members of the path".

It is perhaps unnecessary to mention that verbal descriptions of $d h i k r$, like the one in the present article, belong to the "outer" category. However, a few other parts of this outer dimension should be discussed. The first aspect is $d h i k r$ as an act of purification. The tauhid, la illaha illa-llah "cleanses tamished hearts" (Ozak 1981: 82). "If a person says la ilaha illallah just once with love, he removes four hundred sins" (Ozak 1988: 385). In a more general sense, remembrance is to remove "bad and ugly qualities" from the heart. There is a hadith saying: "All things have a polish. The polish of the heart is the Remembrance of God" (Ozak 1981: 122).

Another important aspect of divine remembrance is the description of different stages. According to Muzaffer Ozak there are seven stages: ${ }^{5}$ Public (audible) dhikr; private (secret) dhikr; dhikr of the heart; dhikr of the spirit; dhikr of the mystery of the spirit; dhikr of the mystery of the inmost heart; dhikr of the mystery of the mystery (Ozak 1981: 67).

These stages correspond to the seven degrees of spiritual development, mentioned in the "Question Manual". Firstly there is the sympathiser

5 In Ozak 1988: 384, the first two stages are omitted. 
(muhib), who visits the dergah or tekke, attends the Sheikh's gatherings (sohbet), and works on the Divine Names. Secondly, there is the disciple or novice (murid), committing himself to the Sheikh's authority. The third degree is the devotee, the sufi, who progressed to the "noble circle", a follower of the obligations of the Sacred Law, "in constant struggle with the carnal self (nafs)". Then comes the degree of the dervish, who in addition to all previous activities obtains peace of mind. The fifth degree is the veli, the friend of God, a stage not described in the text, since it is beyond the "personal accomplishments" of the author. The last two stages are the murshid, the spiritual guide, and fen a fillah, annihilation in God.

The last stage is also described as the ultimate aim of $d h i k r$. In the words of Sheikh Muzaffer: "Love of God is a flame that burns up and annihilates everything in the heart except the love of God" (Ozak 1981: 102). This is the mystery expressed in the words "Die before you die". The same message is repeated in different mystical traditions. The father of neoplatonism, Plotinus (ca. 204-270), uses the words "cut away every thing", i.e. everything that is not the One, the Absolute, in other words different aspects of the human personality (see Plotinus, The Enneads, 5.3.17). The great Christian mystic Meister Eckhart mentions the necessity of "putting aside everything that is yours" ("leg abe allez daz din ist") (Pfeiffer 1924: $209,23 \mathrm{f}$.). Elsewhere I have called this aspect of mystical theology the categorical imperative of mysticism - to reach beyond individuality and loose your self, your ego, in order to dissolve totally in God, thus realising the "true Self". This is what Plotinus describes as "a flight from the alone to the alone". When Eckhart writes that the human soul, at the height of its experience, "sinkt von Nichts zu Nichts", he is probably expressing the same universal experience as Plotinus and the Sufis in their expression fana fi Allah, annihilation in God.

\section{Dhikr as an Act}

\section{Other Descriptions of the Ritual}

Scientific literature treating Sufism is extremely text-oriented, focusing on ancient texts, often written by legendary Sufis. ${ }^{6}$ It is difficult to find detailed anthropological observations of the $d h i k r$ as a ritual act (cf.

\footnotetext{
6 See Baldick 1989, for criticism of the sources.
} 
Kennedy 1974: 205). One of the earliest accounts of the ritual can be found in the well-known book of $\mathrm{E}$. W. Lane, who presents the "Manners and Customs of the Modern Egyptians", first published in 1836.

Lane described several observations of the dhikr ritual in Egypt. Dervishes from different nations and different orders met in a large ring, repeating "Allah" over and over again. At each repetition they bowed the head and body and took a step to the right, so that the circle moved rapidly round. He also observed a Turk, a member of the Mevleviyyah, whirling in the middle of the circle, his arms stretched to his sides and his dress "spread out like an umbrella". After about ten minutes he joined the group and the dervishes now jumped to the side instead of stepping. A smaller circle of six dervishes was formed in the middle, exclaiming the same name at an even higher speed (Lane 1978: $426 \mathrm{f}$.).

At another occasion Lane was in a street called Sook-El-Bekree, close to the burial-ground of a dervish Sheikh. Every Thursday night a dhikr was performed at this place. About thirty persons were gathered, sitting cross-legged upon matting extended close to the houses, forming an oblong ring. At one end of the ring four singers (munshids) were sitting together with a player of the náy-flute. From their position Lane was able to observe and describe the ritual as fully as he could. His observations can be summarized in the following way.

The Sheikh exclaimed "El-Fatihah!", after which the whole group recited the opening Surah of the Koran. They proceeded with a chant, asking God to favour Muhammed and all other prophets and apostles. Then there was a short period of silence and after that another recitation of the Fatihah, this time silently.

After this preface the dhikr started with the formula of divine unity at a slow speed: La illaha illa-llah, bowing the head and body twice at each repetition. After about fifteen minutes they increased the speed, with correspondingly quicker movements. The singers sang portions of a qasidah, a poem, or of a "muweshshah", i.e. "lyric odes in praise of the Prophet" (Lane 1978: 172). Lane translated one of these lyrical odes, which contains a strong emotional tone, not unlike the Song of Songs.

The formula of divine unity was used once again, this time to a different air, for about the same time period. The "zikkeers", as Lane calls them, rose and repeated the same words to another air, emphasizing the word "Lá" and the first syllable of the last word "Alláh".

At this phase in the ceremony "a tall, well-dressed black slave" entered the circle. Lane was informed that the slave was a eunuch belonging to the Basha. The black slave became what is called "melboos" or possessed. 
Throwing his arms about, and looking up with a very wild expression of countenance, he exclaimed in a very high tone, and with great vehemence and rapidity: 'Allah! Allah! Allah! Allah! Allah! lá lá lá lá lá lá lá lá lá lá láá lá láh! Yá 'ammee! [O my uncle] Yá 'ammee! Ya 'ammee 'Ashmáwee! Yá 'Ashmáwee! Yá 'Ashmáwee! Yá 'Ashmáwee!' His voice gradually became faint; and when he had uttered these words, though he was held by a darweesh who was next to him, he fell on the ground, foaming at the mouth, his eyes closed, his limbs convulsed, and his fingers clenched over his thumbs. It was an epileptic fit: no one could see it and believe it to be the effect of feigned emotions; it was undoubtedly the result of a high state of religious excitement. Nobody seemed surprised at it; for occurrences of this kind at zikrs are not uncommon. (Lane 1978: 443 f.)

Another well-known description of the $d h i k r$ ritual was presented by W. H. Haas (1943), who studied the Rahmaniya-order in Algeria, an order which like the Jerrahis in Istanbul is a branch of the Khalwatiyya. The psychophysiological analysis of Haas focuses on the breathing techniques which, Haas is convinced, are of Indian origin. There are, of course, a number of variations between the $d h i k r$ rituals of the different orders. However, the overall pattern of the ceremony is similar to Lane's description and the one presented below. There is a preface, consisting of recitations of litanies; the repetition usually starts with La illaha illa-llah and continues with other divine names like Allah, Hu ("He"), Hayy ("the living"), and Qaiyyum ("the Eternal", or "All Sustaining"). Those names, remarks Gilsenan, emphasize the transcendent, absolute aspects of God. Names like Ya Rahman ("O Merciful One") would imply "be merciful", which is a personal aspect of God not belonging to the proper purpose of $d h i k r$. "The concentration is on the Absoluteness of God, in His Transcendent, Eternal Being, not His attributes such as those of Mercy and Compassion. No action by God is requested, or expected in the dhikr. From this point of view the dhikr is non-instrumental in character" (Gilsenan 1973: 167 f.).

Other similarities are, for example, the changes of tempo, the strong emotional commitment, the rhythmical breathing and rhythmical body movements, reinforced by a group of singers and musical instruments. ${ }^{7}$

\section{Dhikr as an Act - the Halveti-Jerrahis in Istanbul}

It is a Thursday evening in October 1989. On Thursdays dhikr usually is performed. Turkish people from all social strata meet in the dergah (Turkish: tekke) in Istanbul to express their love for God and their longing

\footnotetext{
7 For further descriptions of the ritual see, for example, Kennedy 1974; Gilsenan 1973: ch. VI; Gairdner 1912; Trimmingham 1973: $204 \mathrm{ff}$.
} 
for a direct, personal experience of His Presence. Before the dhikr, most of them perform the evening prayer together. Afterwards the dervishes meet in the big hall of the dergah. There are at least a hundred of them. Many wear short, woollen jackets without sleeves (khirqa), a survival from the early centuries of Sufism, when the ascetics were dressed in woollen garments as "a mark of personal penitence" (Gibb 1957: 132). The dervish receives this woollen frock and a dervish cap (takiye) from his Sheikh during an act of initiation (biyat). For the pupil (murid), this initiation has a special meaning. It connects him with an unbroken chain of transmission, going back from sheikh to sheikh, to the Prophet Muhammed.

As usual there are some guests, other Muslims (or non-Muslims) from Turkey or abroad, visiting scholars, or dervishes belonging to other orders. This time there is a small group belonging to the Rifa'iyah order, also known as the "Howling Dervishes", due to their loud, dramatic dhikr. The presence of the visiting guests reflects the open attitude of the HalvetiJerrahis. The only basic doctrine which the Jerrahis adhere to is tauhid, the unity of God. According to one of my informants the tauhid is "the basis of religion - the verification of the Unity of God, and the belief in all prophets, as bearers of the same message. Belief in the Prophet Muhammed, peace be upon Him, includes belief in all prophets".

Simultaneously, the tauhid expresses the human possibility of coming near to God, who is closer to man as "his jugular vein" (Surah 50: 15). The first part of the doctrine of tauhid, the doctrine of the unity of God, unites the greater part of the world's religions; the second part, the direct experience of union with God, is a common denominator of religious mystics within world religion.

When the Sheikh enters the hall, he greets those present with the words "as salamu 'aleykum", "peace be with you", and the dervishes answer "wa aleykum as selam wa rahmetullahi wa barakatuhuuuu...", "may God's peace, grace, and blessings be with you". The ending "Hu", i.e. "He", one of the divine names of Allah, is prolonged. Then the Sheikh sits down with his back turned to the niche in the wall facing Mecca (mihrab), whereupon the dervishes also sit down with their arms crossed on their chest. As usual there is another dervish, dressed in the garment of the Mevlevi-order, the "Whirling Dervishes". The Mevleviyyah trace their spiritual chain (silsila) to the mystic and poet Jalaluddin Rumi (d. 1273). This feature again illustrates the open-minded attitude or the religious syncretism within the order. The love for God can be expressed in different ways. 
All the dervishes sit on their heels, forming a circle ( $h a l q a$ ), their heads bowed in humility and concentration. The circle is a symbol of unity, and at the same time a representation of the visible world, where the dervishes are gathered to express their love for the beloved - Allah. The whole ceremony is loaded with symbolism. ${ }^{8}$ The sheepskin post, where the Sheikh is sitting, is said to be the symbol of submission, "the mystery of dying before dying".

The Sheikh starts the ceremony with prayers ( $\left.d u^{\prime} a\right)$, and the recitation of the wird, i.e. a litany of Koran verses and prayers, belonging to the spriritual path (tariqa) of the order. He mentions, among others, names of earlier Sheikhs in the spiritual chain of the Jerrahis, asking for their blessing. He also expresses the dervishes' love for Allah and the Prophet. The dervishes respond to the prayer with the word amin, Arabic for Amen. One of the dervishes enters the circle and places an incensory on the floor. Then he bows in front of the Sheikh in the traditional manner: arms crossed on the chest and the right toe on top of the left toe. Symbolically it is the position of the body when laid in the grave. The greeting symbolizes his submission to the will of God, the Prophet, and the Sheikh. He withdraws without turning his back to the Sheikh for at least three steps.

After the $d u$ 'a, the Sheikh says "al-Fatiha", the name of the opening Sura of the Koran, commanding all those present to repeat this Surah mentally to themselves. Then all dervishes sing a devotional chant, a hymn of praise and a prayer to God to bless the prophet Muhammed. Towards the end of the chant the dervishes stretch their hands with the palms upward and rub them in their faces, a symbol of receiving divine blessings. The Sheikh then says more prayers, mentioning prophets and wishing, with their help, to achieve good health for the people present and those not present. About eleven minutes have passed since the Sheikh entered the hall.

The dhikr starts immediately after these prayers. This evening the Sheikh chose to proceed with a song, honouring the unity of God. At a slow tempo the whole group sings the first part of the shahada: La ilaha illa-llah, "there is no God but God", and as a sort of accentuation they repeat the name Allah, three times. For almost ten minutes the dervishes sing these words of divine unity, over and over again, in a melodious way. Then, on a signal of the Sheikh, they increase the speed, mentioning the

${ }^{8}$ The source of this symbolic interpretation is an unpublished pamphlet, distributed among dervishes belonging to the Halveti-Jerrahi order. 
name of Allah only once after the formula of unity. At the same time they turn their bodies to the right when pronouncing the negation of the formula: La ilaha, "there is no God". When uttering the affirmative part of the formula, the words illa llah, "but Allah", they turn their body to the left, the direction of the heart. In order to emphasize this symbolic expression for the love of God, many dervishes put their right hand on their heart.

The mystical interpretation of this first part of the shahada has been described as an illustration of "the movement of going forth and return" (Price 1969: 64). In addition to this Interpretation the author quoted writes as follows. "The emanation of created things, things other (ghair) than God ( ma siwa 'llah), is shown by the words la ilaha (No God), while their return to Him is indicated by illa 'llah (but God). This is the consummation of tawhid (unification), the reintegration of all things in the one from whom they sprang."

After this song of unity the proper dhikr starts. In a monotonous way the words la illaha illa llah are repeated over and over again. The rapidity of the prayer does not permit large body-movements. Instead, the dervishes turn the head to the right and left, in the same symbolic manner as before. The singers play an important role in the ceremony. From a general point of view they stimulate the participants to perform a good dhikr, concentrating on the love for God. More specifically, the song indicates when the $d h i k r$ has to change to a higher or lower pitch. At that moment one of the singers sings a qasida, a hymn of praise directed to the Creator and the Prophet. Such hymns often focus on "the mystery of God's beauty and majesty, His grace and wrath, and the marvels of creation" (Schimmel 1975: 163). Most dervishes keep their eyes closed in order to concentrate on the dhikr and the melodious songs.

After only two and a half minutes the Sheikh claps his hands as a signal to increase the speed. In the meantime, one of the more advanced dervishes enters the circle, bringing some pieces of clothes on a tray and a bottle of water. The clothes normally belong to members of the dervishes' families. The water was fetched from the well close to the burial-place of the former Sheikhs of the order. All the dervishes in the inner circle, where the more spiritually mature are sitting, breathe on the objects in order to transmit the divine power obtained during the $d h i k r$. This power will be beneficial to the persons to whom the pieces of clothes belong. The water will be given to other sick people. Since the Sheikh is regarded as a person possessing great power, the dervish in charge of this particular ritual dwells no less than about forty seconds in front of him, waiting for 


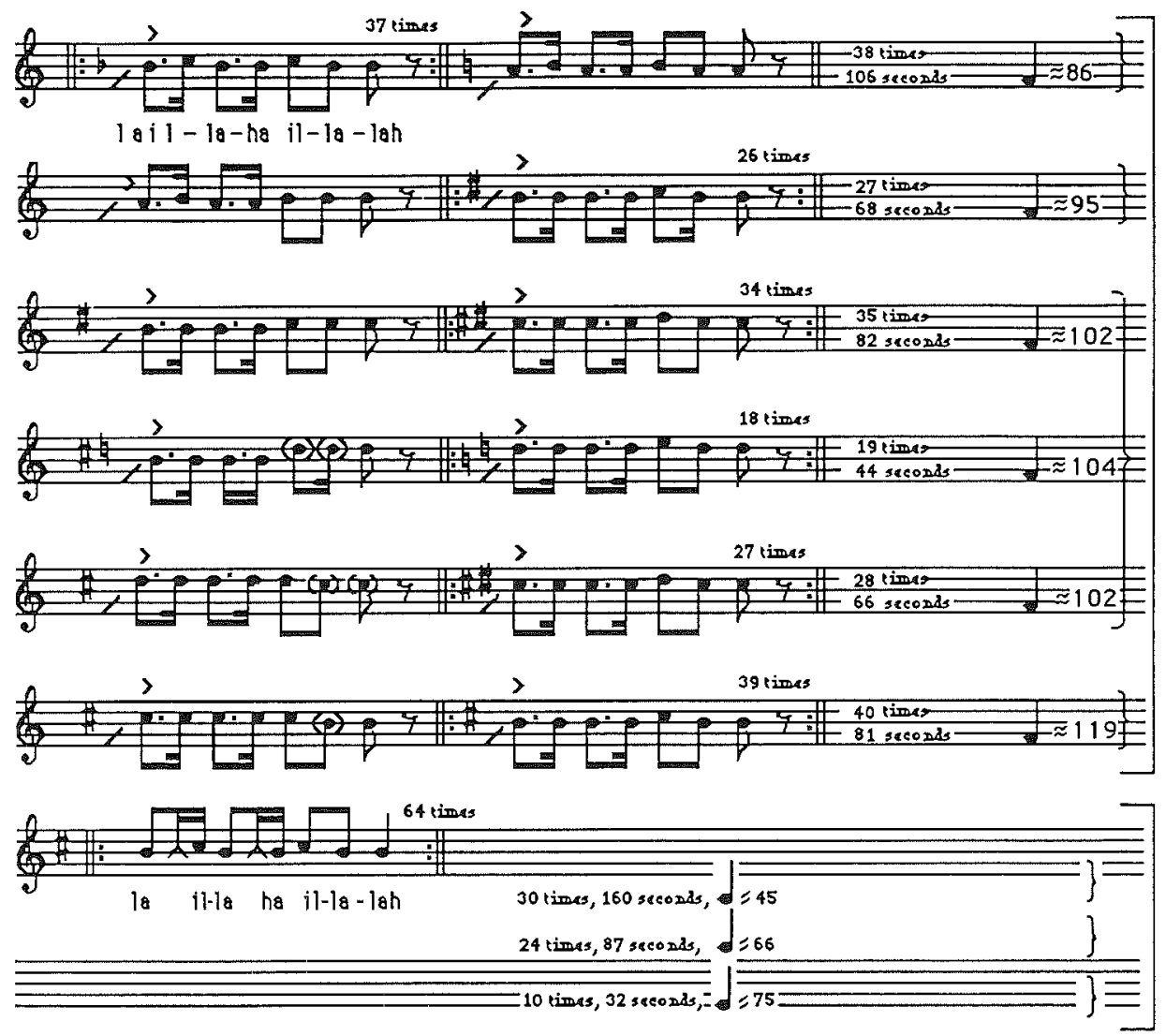

A notification of la illaha illa llah at different tempi. $\wedge$ is a symbol for strong inhalation. (The author wishes to thank Håkan Lundström, music-anthropologist in Malmö, for the notifications.)

the Sheikh to breathe out upon the object. The objects are held only one or two seconds in front of the other dervishes. In the words of one of the more experienced dervishes: "The Sheikh is the channel through which the healing power of God flows."

As soon as the objects are being carried away, the Sheikh, after a little more than five minutes, again claps his hands in order to increase the speed of the dhikr. After about one and a half minute the Sheikh signals again, this time changing to a slower speed, but still using the same formula, expressing divine unity. The lower speed enables the participants to sway and simultaneously bow their bodies to the right and the left in large movements. The eyes are still closed. The speed of this dhikr increases 
two times, first after about three minutes, then again after one minute and forty seconds. Half a minute later the Sheikh announces the end of this part of the dhikr. The dervishes remain in a short moment of silence, awaiting the next divine name.

This particular evening the Sheikh exhibited another deviation from the traditional Jerrahi dhikr. In most cases there will be a recitation from the Koran at this point of the ritual. Today the dervishes, at a signal from the Sheikh, continued with short, thrusting repetitions of the word Allah. During these repetitions the dervishes turn the head rhythmically to the left. Like earlier this evening, the Sheikh claps his hands on two occasions in order to increase the speed; the first time after one minute, and the second time after about forty seconds. Almost one minute later the Sheikh stops the prayer. This $d h i k r$ is not accompanied by recitations or songs.

The next divine name in the ritual is $H u$, i.e. "He". When repeating this holy name, the dervishes make minor movements of the head towards the left. It is a short exercise, lasting only one minute, without accompaniment of the singers. When ended, one of the singers recites four verses from the Koran, to be precise Surah al-Anfal (8: 1-4):

They will question you concerning the spoils. Say: 'The spoils belong to God and the Messenger; so fear you God, and set things right between you, and obey you God and His Messenger, if you are believers.' Those only are believers who, when God is mentioned, their hearts quake, and when His signs are recited to them, it increases them in faith, and in their Lord they put their trust, those who perform the prayer, and expend of what We have provided them, those in truth are the believers; they have degrees with their Lord, and forgiveness, and generous provision. (Transl. by A. J. Arberry)

The headline of the Surah, "The Spoils", refers to the battle of Badr in AD 624. It is difficult to understand how the first verse could be related to the $d h i k r$, unless you apply an allegorical interpretation, which is quite common within Sufism. According to one of my informants the first part of the verse quoted refers to the "greater war", i.e. the war with the ego, the carnal self. The following three verses are, of course, loaded with significance for the dervish. This is the time when his heart is filled with love for God and trust in his words, as revealed in the holy Koran, being recited at this very moment. During the recitation the dervishes sit relaxed, contemplating the revelations of the Creator.

Directly after the recitation the Sheikh says a prayer of a similar type as during the initial phase of the ritual. It is a prayer expressing good 
wishes for all people, and asking for blessings from the prophets. As before, the dervishes respond with the word amin. Then the Sheikh says "al-Fatiha", and the dervishes respond: "Allahumma salli "ala seyyidina Muhammad". The words express a benediction upon the Prophet, asking God to bestow blessings upon him. Afterwards all the dervishes repeat the Fatiha silently. This is the end of the first phase of the $d h i k r$.

During the second phase of the ritual the dervishes are standing up, arms crossed on their bellies, still forming a circle. They start to sing a song similar to the former initial phase, praising divine unity. The song lasts for slightly more than two minutes. After that the Sheikh says a short prayer, to which the dervishes again respond with the words "Allahumma salli 'ala seyyidina Muhammad". This sort of dialogue-prayer is repeated three times. Then the Sheikh says $Y a$, Allah! and the dervishes answer with the divine name $H u$. At this moment the dervishes take each others' hands and start to move to the left in the circle, in the direction of the heart. There is a cosmological symbolism hidden in the circling of the dervishes. The whole universe circles, like planets around the sun, like electrons around their atomic nucleus. In the words of Muzaffer Ozak: "The entire universe is dancing and whirling with God's love" (Ozak 1981: 114).

While the dervishes are pronouncing the name $H u$ they turn the head to the left. In the background we hear the singers sing an ilahi, a devotional song. Most of them are in Turkish. One of the favourite poets in the Jerrahi-tradition - and all over Turkey - is the medieval poet and mystic Yunus Emre (d. ca. 1321). It is typical of the style of Yunus Emre, and other Turkish popular poets, to mention his own name in the last verse of the poem.

The singing of the name $H u$ lasts for hardly a minute. Then we arrive at a dramatic and beautiful moment in the ceremony. The Sheikh raises his voice and pronounces another of "the ninety-nine beautiful names" of Allah: Hayy, "life", "always living". The dervishes release their hands, put their left hand on the left shoulder of the dervish on one side, and the right arm around the waist of the dervish on the other side. They continue to move in the circle, the right foot slightly behind the left one. The Mevlevi-dancer starts his elegant dance in the centre of the circle and the singers raise their voices in order to inspire the dervishes with another beautiful ilahi. Rhythmically and with feeling the dervishes repeat the name: eh-hayy, eh-hayy, eh-hayy, strongly exhaling, and simultaneously turning to the left. Most of them still have their eyes closed and express their feelings in a blissful smile. Annemarie Schimmel has described the 
impression you can receive as a participant-observer, words with which I can fully identify (Schimmel 1975: 176):

Anyone who has had the opportunity to attend such a rhythmical dhikr, with its increasing tempo and its reduction of words until a kind of permanent sighing is reached, knows that even a noncommitted listener is easily carried away by the strength of the experience.

In the beginning of this part of the ceremony, the Sheikh frees himself from the circle and invites the guests from the Rifa'i-order to practise their own style. In two pairs, standing opposite each other, dressed in black caps, as contrasted to the white caps of the Jerrahis, the Rifa'i dervishes cross their arms and move rhythmically to the right and left while repeating the divine name.

This is a rather long part of the dhikr, lasting about six and a half minutes. Then the Sheikh signals with claps of his hands in order to increase the tempo. The singers take up another ilahi; the dervishes move faster in the circle. Two dervishes play the drum in order to indicate the rhythm. Slowly, the speed increases more and more. Suddenly, almost two and a half minutes later, the Sheikh pulls one of the higher dervishes out of the circle. The guests are signaled to stop with their style and join the group, which is now regrouping in a spiral, encircling the Sheikh. After a short while the turning stops. The dervishes continue repeating Hayy, which is all the more impressive since the singers just stopped their song. Only the sighing sound of a short, thrusting, pulsating Hayy is audible while the dervishes at the rhythm of the drums bend and stretch their knees. It is like a "universal breath of mankind, breathing in unison, breathing as one body and beating as one heart reaching for God" (see note 8 ). The Sheikh is at the centre, standing still, and representing the qutb, "pivot", symbolizing the axis mundi or the Pole around which the spriritual life of the dervishes revolves. After a short while a solo singer starts to sing a prayer, expressing peace and blessings from the prophets.

We are now approaching the end of the second phase of the $d h i k r$. For a short moment, one and a half minute only, the dervishes repeat the divine name tauhid, i.e. the unity of God. Some of the dervishes shout "Hayy" in a strong emotional way, seemingly out of order. Then the Sheikh again signals to take up the name Hayy, which the dervishes repeat at a high speed. During half a minute only they pronounce Hayy about sixty times, while bending their bodies vertically up and down. Then the prayer stops abruptly. The Sheikh says a few prayers, the dervishes answer amin. 
Finally one of the guests says "al-Fatiha", to which the group responds with the words "Allahumma salli 'ala seyyidina Muhammad".

The third phase is quite different from the first two, at least as far as the position of the dervishes is concerned. Instead of a circle they are now standing in rows opposite each other. In between the two groups of rows, sheep-skins are placed on the floor. This is the place where the Sheikh and the singers will be sitting shortly. As contrasted to the first two phases, when the singers were in a position outside the circle, they are now "inside", i.e. in between the two groups of rows. On the short side of the rows, opposite the mihrab, young boys are standing. From there they can both observe and participate in the dhikr ritual.

While the dervishes are regrouping and the sheep-skins are being laid on the floor, all the dervishes sing an ilahi. The song also marks a break, a short period of rest, during which the dervishes concentrate on the final phase of the ritual. After the ilahi the Sheikh says a few short prayers, to which the dervishes respond with the same phrase as that mentioned above. Then one of the dervishes starts repeating the name Allah in a rather slow, singing manner. Soon they all join, while the singers and the Sheikh in the middle sit down between the two rows. When seated, the singers start an ilahi, which intermingles with the large group, singing their devotion to Allah, bending their bodies rhythmically to the right and the left. After hardly two minutes, when the name of the poet is mentioned, the Sheikh gives the signal to change to another divine name. At a slightly higher speed and with strong commitment the dervishes praise their creator with the words Allah-hayy, "Allah-the living one", "life", keeping their right hand on the chest. The bodily movements are somewhat different now. The dervishes still bend their bodies to the right and the left, but the difference is as follows. After bending the body to the right, they stretch up, lean back to the left and turn their head ninety degrees to the right, repeating the same movement in the other direction, over and over again. While the dervishes are moving as described, the singers are engaged in an ilahi written by Yunus Emre.

After about one and a half minutes, shortly after the name Yunus has come up, the dervishes change $d h i k r$ to the word Hayy, strongly exhaling and with a short "eh" before - eh-hayy, eh-hayy, eh-hayy. The speed is about forty-eight repetitions a minute. The sound of the drums keeps the rhythm of the dhikr. Many of the dervishes are smiling. A solo singer expresses his love for Allah with a qasida. When he finishes, the group of singers take over and sing a new ilahi, followed by another solo singer. Poems are usually sung by a solo singer and they are taken up 
spontaneously. Ilahis are selected before the dhikr-ritual.

After four and a half minutes the tempo of the dhikr increases to sixty repetitions a minute. A solo singer accompanies their prayer with another hymn of praise. About one and a half minutes later the speed increases to eighty-six repetitions a minute, while the singers take up a new ilahi, followed by a blind hafiz (who knows the Koran by heart) singing a poem. Almost three minutes later the group of dervishes change $d h i k r$, saying Allah ya da-im, i.e. "Allah, oh Everlasting One". At first the speed is rather slow, about twelve repetitions in a minute. The voices are going up and down, following the tone of the singer. The body movements are rather peculiar. With relaxed arms and while bending their knees the dervishes turn ninety degrees to the right and to the left. When turning to the left, they put their right hand on the chest, in the region of the heart. The repetition of this name continues for another four minutes, accompanied by several solo singers.

After this tribute to the immortal God, the dervishes take up a new divine name, which is difficult to identify because of the strong breathing sound. According to a blind hafiz, trained as he is to listen, it is AllahAllah-Hayy. The exhaling rhythms can be divided into three parts: longshort-long, all in one period of exhaling. In the background we hear solo singers and ilahi's, sung by all singers. This part of the ritual lasts for about five minutes. The dervishes either cross their hands on their bellies or grip the lapels of their khirqa. They sway rhythmically to the right and the left, and simultaneously up and down by bending their knees.

For about half a minute the dervishes are silent. The singers take up a new ilahi, accompanied by heavy strokes on the drums. Immediately after the ilahi a solo singer starts his song and the Sheikh claps his hands in order to indicate the tempo of the new dhikr to come. The dervishes now return to the divine word Hayy, pronouncing it at a speed of about ninety words a minute. The relatively high speed of the repetitions does not allow large body movements. The dervishes bow slightly forward, bending their knees rhythmically at the same time. After almost three minutes, the tempo increases to one hundred repetitions a minute, a speed which they keep up for about two minutes. Then the singers slow down the tempo, resulting in the slowering down also of the $d h i k r$. The Sheikh rises to his feet and indicates the rhythm of the next divine name: $H u$. During almost a minute the dervishes pronounce $H u$ at a speed of about ninety repetitions a minute. The body movements are more quiet now. The dervishes bend their bodies slightly forward at each repetition. In the background a solo singer starts his hymn of praise. 
We are now approaching the end of the ceremony. The Sheikh says a few short prayers, the dervishes answer with the word amin. The dervishes are standing still with their arms crossed on their chest. Some of the guests say "al-Fatihah" and the dervishes respond with the same words as those mentioned above. Their hands are stretched out in front, in a gesture of receiving, and then put to their faces in order to take in the beneficial value of the blessings. The last "al-Fatihah" is pronounced by the Sheikh. The ending ceremony consists of a song, praising the greatness of Allah. Immediately after that the whole group pronounces the name Allah, without stopping, a moment during which some dervishes, a Sheikh or elder, say some prayers at a very high speed. Suddenly one of the dervishes, one of the guests from the Rifa'i order, raises his voice, saying a long ya Allah, and all the dervishes respond with a long, extended Huuuuu in a successively lowering voice. Finally the Sheikh leaves the room, saying "as salamu aleykum", and the dervishes answer with the words "wa aleykum us-salam wa rahmatullahi wa barakatuhu", "may God's peace, grace, and blessings be with you".

After the dhikr the dervishes sit down in small groups, talking to friends and drinking tea. The Sheikh returns to the group and gives those present a chance to ask questions, either in public or in private. Usually it is late at night when they all return to their homes.

\section{Dhikr - a Multi-dimensional Psychological Commentary}

As has been mentioned above, psychological commentaries on the effects of $d h i k r$ are extremely scarce. One of the few existing ones was published almost half a century ago by Haas (1943), who studied the RahmaniyaOrder in Algeria. Haas emphasizes two aspects, two ways which "converge to bring about the final state of abnormal consciousness, the hal. The one uses the technique of suggestion and hypnotism; the other relies on the technique of breathing". Both the recitations, the litanies and the form of the circle, Haas continues, facilitate the atmosphere of suggestion. In addition to these factors Haas mentions "the role of the Sheikh, how he fixes his eyes upon the friars as any hypnotizer does" (Haas, 1943: 24 f.). This last mentioned observation may have been valid during the time and in the place where Haas performed his study. My experience from the Halveti-Jerrahi order of dervishes in Istanbul during the years 1989-90 is quite different from the observations of Haas. ${ }^{9}$

\footnotetext{
9 After reading this statement of Haas, my informant sent me the following story. "A dervish once brought home his brothers each a moustache comb. The Shaikh on
} 
Haas touches upon some of the levels of analysis I mentioned in the introduction of this article. My comments will now be structured in accordance with these four levels, with the emphasis on the psychological interpretation of the ritual.

At the socio-cultural level we cannot, of course, underestimate the importance of the religious tradition in general and the history of Sufism in particular. It is reasonable to assume that most members of the HalvetiJerrahi order have not studied the basic texts of Sufism. The most important way of transmitting this tradition is through direct, verbal instruction, through informal discourses (Irshad) of the type published in the book "Wisdom of a Sufi Master" by Sheikh Muzaffer Ozak (Ozak 1988). Another way of transmission is on the personal level: questions and answers (Turk.: Sohbet). The dervish is supposed to reveal his life to the Sheikh, who also gives advice on personal matters and interprets dreams. In addition to these factors I can also mention the different pamphlets and other printed and photo-copied material spread among the members of the order. As far as the new generation is concerned, young boys are allowed to participate in the $d h i k r$, as part of their religious socialisation.

At the social-psychological level I referred to the concept of reference groups as defined by T. Shibutani (1955). The advantage of this concept, for our purpose, is that it also focuses on perceptual dimensions of group dynamics. Bearing this concept in mind we can observe the following factors.

The dervishes belonging to the Halveti-Jerrahi order are a reference group, sharing the Halveti-Jerrahi definition of reality, consisting of their own texts, songs, poems, and their own tarikat-jargon or symbolic language. Every time a member of the order meets in the tekke, this part of their overall definition of reality, this perspective, is particularly activated. This is the perspective used to define the situation: an evening dedicated to the practice of $d h i k r$, leading possibly to a direct experience of His Presence, a "taste" of God. This is an important part of the expectations the dervish has on a Thursday evening. The responses of the groupmembers imply a reinforcement of this perspective. Besides being an evening dedicated to dhikr, it is also a social evening, when the dervishes share a meal together, chat, exchange ideas, and listen to their Sheikh.

The dervis hes are also aware of the place they have in the group, having certain responsibilities and occupying certain places in the spiritual hier-

receiving none, asked: 'And where is mine?' whereupon the derwish replied: 'I did not know you had a moustache'. In twenty years he had never raised his head in the presence of the Shaikh." (So where then is the effect of the "hypnotic gaze?"). 
archy. Concerning the last mentioned aspect, however, my informants told me that only the Sheikh knows their exact stage of spiritual development. They only have an approximate idea of their spritual maturity, and they are usually well aware of the "elders" in the group.

During the dhikr the importance of the unity of the group is stressed by the way the group is formated - in a circle and as two lines of rows opposite each other. Another factor stressing the unity of the group is the dervishes holding each others' hands or putting one arm on the shoulder and the other around the waist of the dervishes next to them. When, in the ritual, all the dervishes circle in a spiral around their spiritual leader, the importance of the Sheikh can hardly be observed with greater clarity.

This brings us to the question of the role of the Sheikh and the relation between him and the group of dervishes. Submission under the guidance of the Sheikh is of the utmost importance. In the words of Sheikh Muzaffer: "Those who wish to be able to attain Reality and to experience Inner Knowledge of the self, by obediently worshipping God, Exalted is He, with his sincerity, absolutely must submit to the instruction and training of a perfect spiritual guide" (Ozak 1981: 150).

The Sheikh as the "connecting Bond" (Ozak 1981: 155) should always be respected and kept in mind. When approaching the Sheikh, the pupil should be in a state of external and internal ritual ablution (Ozak 1981: 158). The role of the Sheikh for the dervishes, as spiritual guide, adviser, interpreter of dreams, cannot be underestimated. In the words of Yunus Emre (quoted in Ozak 1981: 170):

Come, brother, if it's the Truth you seek, There's only one way - through a perfect guide.

The Sheikh is the one who directs the $d h i k r$ ritual. The dervishes are extremely receptive to the directions given by him during the ritual. Even if during the $d h i k r$ the pupil forgets himself, he should be aware of his Sheikh. This is called "the degree of annihilation in the Sheikh" (Ozak 1981: 158). After this degree of fana there are three deeper levels of annihilation: in the Founding Saint of the Order; in the Messenger; and in God (Ozak 1981: 158).

With the concept of fana we touch upon the third, psychological dimension. Just as the dervishes themselves make a distinction between different degrees of fana, we can from a psychological point of view differ between partial and total annihilations. The question is whether we can find out which components of the human personality are being annihilated. In 
order to reach such an understanding it is necessary to start the analysis from a model of personality. The model I have been using for several years now is based on ego psychology, especially its cognitive dimensions.

The ego is a rather complex structure in modern psychology. Epstein distinguishes between the representational and functional aspects of the ego. With the help of the former, the individual constructs a differentiated view of himself and the outside world, called self- and object-representations. The functional system consists of adaptive, defensive, mediative and synthetic functions. I will now introduce a more detailed presentation of these aspects of the system ego. It is important to remember, however, that it is a theoretical model of a complex structure, a dynamic system which, like a thermostat, all the time strives after equilibrium or homeostasis.

The first substructure in the functional system is called the adaptive functions of the ego, a term connected with the work of Heinz Hartmann (1958). The adaptive functions are responsible for adaptation to reality. It has at its disposal a number of abilities or dispositions which are inherited, e.g. perception, memory, intelligence, language. These functions are autonomous and they help the human being to adapt to this environment. The concept adaptation refers to all processes that serve man's biological, psychological, and social survival. With this concept Hartmann connected psychoanalysis with both cognitive and social psychology. It is difficult to understand the complex human being without taking these important branches of psychology into consideration.

Classical psychoanalysis talks about the constant war of the ego, a war with three fronts: impulses from the id, the norms and values of the super-ego, and the demands of the environment. The most important weapon system at the disposal of the ego are the defensive functions. They also serve man's adaptation to his environment, more particularly to his psychological environment. In contrast to the former function, however, the ego's defence mechanisms are not inherited but acquired under the influence of the socio-cultural milieu. Anna Freud (1946) has presented a systematic survey of man's defence mechanisms which are activated in order to cope with threatening impulses from the unconscious id. We should remember, however, that the ego can use any psychological process to achieve its goal: to avoid psychological pain, chaos, and establish order.

The third substructure in the ego's functional system is called the mediating function, which corresponds to the classic psycho-analytical view of the ego - acting as a mediator between the id and the super-ego, or between the id and the environment. In the course of development the ego 
successively increases its control over the impulses from the id. Naturally, the defence mechanisms play a considerable role in this controlling process. This illustrates once again that the different functional parts of the system ego should be regarded as a whole, not as isolated parts.

The synthetic function is the fourth and last substructure in the functional system of the ego. It is an "organ of equilibrium" (Hartmann 1958: 39), which strives for balance in a constantly shifting psyche. The synthetic function "assimilates alien elements (both from within and from without), and it mediates between opposing elements and even reconciles opposites and sets mental productivity in train" (Nunberg 1961: 122). The most important synthetic functions, according to Nunberg, can be summarized with the following concepts: assimilation, simplification, generalization, unification. Nunberg emphasizes, however, that the synthetic function can use any psychic process in order to achieve its goal: equilibrium, order, balance (1961: 125). Even "hierarchies of values" can have a synthetic function. In this context Hartmann points to the psychological importance of religion as an integrating factor (Hartmann 1958: $75 \mathrm{ff}$.).

The other large substructure in this ego-psychological model of man is the representational system, i.e. the process of relating to and representing objects. An object can be a thing, a person, or a happening. This theory belongs to the great landmarks of psychoanalysis during the $60 \mathrm{~s}, 70 \mathrm{~s}$, and $80 \mathrm{~s}$. It is my impression that the distinction between the ego's functional and representational system is no longer a point of great controversy (see e.g. Hartmann 1958; Sandler and Rosenblatt 1962; Jacobson 1964; Schafer 1968; Rizzuto 1979; Rothstein 1981; Epstein 1988). According to Rothstein the two systems are in an important way related to each other. He mentions, for example, that this relation facilitates our understanding of "intrasystemic conflicts" (Rothstein 1981: 440).

Inner representations are closely related to memory, with the help of which we code, process, and store information, which can be retrieved in useful forms in specific situations. The end of this process is called a representation. This means that a representation cannot be regarded as an isolated happening. In the words of Rizzuto: "it is the result of the synthetic function of the ego organizing a multitude of memorial experiences. The final synthetic result of that most active process is a highly significant representation for the needs of a particular moment" (Rizzuto 1979: 56). Rizzuto mentions here another example of the relation between the functional and representational system.

The representational system consists of self- and object representations "in ever changing states of integration" (Rothstein 1981: 440). The basic 
task of this system is to make us "psychologically viable people in the real world" (Rizzuto 1979: 55). In other words, it serves the overall need of adaptation.

During the course of development a self- or "I" representation will be developed within this inner representational world. This means that, in this model, the "I" is not identical with the ego. The "I" is rather one component in a composite structure. The "I" is described as "the selfrepresentation as agent". The "I" is developed from the ego's continuous sensation of itself (Rothstein 1981: 440; Epstein 1988: 64). Development means increased differentiation and integration. During this process the "I" is differently constructed in relation to other substructures of the ego. This implies that there is not one single "T" but multiple selfrepresentations, actualized in different situations.

From this point of view the $d h i k r$ can be described in the following way. The repetitions of divine names with corresponding movements of the body are examples of verbal and motoric monotony. This monotony can lead to an alteration of ordinary perceptual and cognitive processes, in other words a partial inhibition of the ego's adaptive functions. The relation to the environment is partially inhibited. This simultaneously means a weakening of the defensive functions, which explains why certain dervishes give free way to their emotions. Such expressions can also be observed during the Friday prayer. Recitation of the Koran in the mosque can be extremely emotional, leading to Muslims getting in touch with suppressed anger or other feelings. Such happenings are rather common during $d h i k r$ exercises and they are generally accepted by the group. I have observed this phenomenon on almost every occasion. The dervishes in question move a-rhythmically and exclaim their agony in shouting the name of Allah and phrasing their feelings in different ways.

On the representational side of the personality model we can describe the $d h i k r$ ritual as an activation of those representations which are connected with the ritual, i.e. a specific part of the perspective of the Suf. The whole object of the ritual is to lose self-consciousness, to be annihilated in the Sheikh, the Founder of the Order, the Messenger, or Allah. In the words of my informant this means "submission of personal will, of the self to the group. ... The dhikr should be done so as not to be aware of your own voice. ... Thereby, the individual becomes able to overcome the illusion of his false 'Self' consciousness". From our point of view this is, in most cases, not losing self-consciousness, but to inhibit the representation of the "I" as an acting agent. This does not lead to an inhibition of the complex ego structure. 
The functional and representational aspects of personality are naturally related to each other. The monotonous exercises not only alter the dervish's relation to his environment, they simultaneously inhibit the "I"-representation as an active agent. This is one of the most common experiences in world-religions, described as mushin ("without mind" or "without minding") in Zen-Buddhism, the experience of anatta ("noself") in buddhism, as "Entwerden" or "Entmenschen" by the German mystics and wu-wei ("non-action") by Chinese Taoistic philosophers. This common experience leads to a more of less differentiated view of man, to a mystical psychology, also well-known within Sufism (see, for example, Shafii 1985). At the bottom of this personality there is the human capacity to reach union with God, in Sufism the Sirr Allah.

I assume that the majority of dervishes do not enter into an altered state of consciousness in the sense that they lose the experience of the "I" as an active agent. This, of course, is a rare experience within Islam as in other world-religions. Inhibitions of functional and/or representational aspects of the human personality are most often partial with, in the case of the dervishes, continued awareness of, for example, signals from the Sheikh. However, it is reasonable to assume that most dervishes experience changes in their organisms, due to their specific way of breathing. We now touch upon the fourth and final level of analysis - the physiological level.

The aspect of hyperventilation in connection with Sufi practices has been pointed out by, among others, David M. Wulff (1991: $71 \mathrm{ff}$.), who relies mainly on the research of Rouget (1980). Physiologists usually discuss the hyperventilation syndrome, exhibiting symptoms like cramp, dizziness, light-headedness, stiffness, and tetany (Smith 1985). From my point of view, however, it is important to study this biological aspect within the context of the four levels of analysis. In this way we are able to avoid the "nothing-but-fallacy" reducing intense religious experiences to a biological level. This type of medical materialism has been criticized all the way from the famous classic of William James (1902) to the epochmaking work of David M. Wulff (1991: $106 \mathrm{ff}$.). Physiological changes like dizziness or light-headedness are interpreted within the frame of reference of the Sufi world-view, with or without the aid of the Sheikh, who in his turn relies on the Sufi tradition of $d h i k r$ and its Koranic justifications. Again, this is an argument for a multi-dimensional analysis of intense religious experiences. 


\section{References Cited}

Anawati, G.-C., and L. Gardet

1961 Mystique musulmane. Paris.

Baldick, J.

1989 Mystical Islam. An Introduction to Sufism. London: J. B. Tauris \& Co.

Berger, P., and T. Luckmann

1966 The Social Construction of Reality. A Treatise in the Sociology of Knowledge. New York. Anchor Books.

Epstein, M.

1988 The Deconstruction of the Self: Ego and "Egolessness" in Buddhist Insight Meditation. The Journal of Transpersonal Psychology 20: 61-69.

Freud, A.

1946 Jaget och dess försvarsmekanismer. Stockholm: Natur och kultur.

Gairdner, W. H. T.

1912 "The Way" of a Mohammedan Mystic. The Moslem World 2: 171-181.

Gardet, $\mathbf{L}$.

1965 Dhikr. In: Encyclopaedia of Islam; vol. 2: 223-227. Leiden: E. J. Brill. [New ed.]

Geels, A.

1990 Extatisk religion. Ett bidrag till mystikens psykologi. Lund. (Religio. Skrifter utgivna av Teologiska institutionen i Lund)

1991 Att möta Gud i kaos. Religiösa visioner i dagens Sverige. Stockholm: Norstedt.

Gibb, H. A. R.

1957 Mohammedanism. An Historical Survey. London: Oxford University Press.

Gill, S. D.

1987 Prayer. In: Mircea Eliade (ed.), The Encyclopedia of Religion 11: pp. 489494. New York: Macmillan Publishing Company.

Gilsenan, M.

1973 Saint and Sufi in Modern Egypt: An Essay in the Sociology of Religion. Oxford: Oxford University Press.

Haas, W. S.

1943 The Zikr of the Rahmaniya-Order in Algeria. The Muslim World 33: 16-28.

Hartmann, $\mathbb{H}$.

1958 Ego Psychology and the Problem of Adaption. New York: International University Press.

Jacobson, E.

1964 The Self and the Object World. New York: International University Press.

James, W.

1902 The Varieties of Religious Experience. New York: Longman, Green, and Co.

Kennedy, J. K.

1974 The Nubian Dhikr Rituals and Cultural Change. The Muslim World 64: 205219.

Lane, E. W.

1978 (1836) Manners and Customs of the Modern Egyptians. The Hague. 
Nasr, S. H.

1988 Preface. In: Muzaffer Ozak, Irshad. Wisdom of a Sufi Master; pp. vii-x. New York: Amity House.

\section{Nunberg, $\mathbf{H}$.}

1961 Practice and Theory of Psychoanalysis. New York: International University Press.

Ogén, G.

1982 Religious Ecstasy in Classical Sufism. In: Nils G. Holm (ed.), Religious Ecstasy; pp. 226-240. Stockholm: Almqvist \& Wiksell International. (Scripta Instituti Donneriani Aboensis, 11)

Ozak, Muzaffer

1981 The Unveiling of Love. Sufism and the Remembrance of God. New York: East West Publications.

1988 Irshad. Wisdom of a Sufi Master. New York: Amity House.

\section{Pfeiffer, F.}

1924 Meister Eckhard. Neudruck. Göttingen. (Deutsche Mystiker des 14. Jahrhunderts, 2)

Price, C.

1969 The Persian Sufis. London: George Allen and Unwin.

Rizzuto, A.-M.

1979 The Birth of the Living God. A Psychoanalytical Study. Chicago: University of Chicago Press.

Rothstein, A.

1981 The Ego: An Evolving Construct. International Journal of Psychoanalysis 62: $435-445$.

Rouget, G.

1980 Music and Trance. A Theory of the Relations between Music and Possession. Chicago: University of Chicago Press.

Sandler, J., and B. Rosenblatt

1962 The Concept of the Representational World. Psychoanalytic Study of the Child 17: 128-145.

Schafer, R.

1968 Aspects of Internalization. New York: International University Press.

Schimmel, A.

1975 Mystical Dimensions of Islam. Chapel Hill: University of North Carolina Press.

1987 Secrecy in Sufism. In: Kees W. Bolle (ed.), Secrecy in Religions; pp. 81-102. Leiden: E. J. Brill.

1990 Sufismus und Volksfrömmigkeit. In: Munir D. Ahmed et al., Der Islam 3; pp. 157-241. (Die Religionen der Menschheit, 25, 3)

Shafii, M.

1985 Freedom from the Self. Sufism, Meditation and Psychotherapy. New York: Human Science Press.

Shibutani, $\mathbb{T}$.

1955 Reference Groups as Perspectives. The American Journal of Sociology 60: $562-569$. 
Smith, C. W.

1985 Hyperventilation Syndrome. Bridging the Behavioral-organic Gap. Postgraduate Medicine 78: 73-84.

Sukri Efendi, Zakir

1980 Mecmu'a-i Tekaya. In: Klaus Kreiser (ed.), Die Istanbuler Derwisch-Konvente und ihre Scheiche. Freiburg: Klaus Schwarz Verlag.

Trimming ham, J. Spencer

1973 The Sufi Orders in Islam. Oxford: Oxford University Press.

Yola, Senay

1982 Schejch Nureddin Mehmed Cerrahi und Sein Orden (1721-1925). Berlin: Klaus Schwarz Verlag.

Wulf, David M.

1991 Psychology of Religion. Classic and Contemporary Views. New York: John Wiley \& Sons. 